Syntax Literate: Jurnal Ilmiah Indonesia p-ISSN: 2541-0849 eISSN: 2548-1398

Vol. 6, Special Issue No. 2, Desember 2021

\title{
KOMUNIKASI KRISIS EIGER DAN TANTANGAN PERBAIKAN REPUTASI DI ERA DIGITAL
}

\author{
Ahmad Faiq Syukron \\ Universitas Diponegoro, Semarang, Jawa Tengah, Indonesia \\ Email: ahmadfaiqs@gmail.com
}

\begin{abstract}
Abstrak
Surat Keberatan yang dibuat oleh Eiger justru menjadi sebuah boomerang ketika surat tersebut diunggah oleh seorang Youtuber melalui akun Twitternya @ duniadian hingga menjadi trending topic yang kemudian memicu reaksi doxing yang dilontarkan oleh warganet dan memunculkan sebuah krisis bagi Eiger yang merupakan sebuah produsen brand ternama yang sebelumnya mempunyai reputasi yang baik. Dengan menggunakan metode kualitatif deskriptif, penelitian ini mencoba untuk mengidentifikasi dan menjelaskan bagaimana Public Relations dari Eiger menangani krisis tersebut dengan menggunakan strategi tanggap krisis dalam konsep Situational Crisis Communication Theory dan mencoba mengembalikan reputasi baiknya dengan menggunakan konsep Image Repair Theory.
\end{abstract}

Kata Kunci: komunikasi krisis, public relations, situational crisis communication theory, image repair theory

\begin{abstract}
The Letter of Objection made by Eiger actually became boomerang when the letter was uploaded by YouTuber through his Twitter account @duniadian to become a trending topic which then triggered a doxing reaction thrown by netizens and caused a crisis for Eiger which is a well-known brand manufacturer that previously had a good reputation. Using descriptive qualitative methods, the study attempts to identify and explain how Eiger's Public Relations handles the crisis by using crisis response strategies in the Situational Crisis Communication Theory concept and attempts to restore its good reputation by using the concept of Image Repair Theory.
\end{abstract}

Keywords: crisis communication, public relations, situational crisis communication theory, image repair theory

\section{Pendahuluan}

Eiger, brand ternama produsen berbagai kebutuhan perlengkapan dan peralatan bagi gaya hidup para penggiat alam terbuka asal Indonesia, sempat menjadi trending topic warganet Twitter akhir bulan Januari, tepatnya pada tanggal 28 Januari 2021. Seperti yang diberitakan Tirto.id, pada tanggal itu setidaknya terdapat lebih dari 45.800 tweet yang menyangkut soal Eiger dan Youtuber Dian Widiyanarko dengan akun Twitter@duniadian. 
Insiden viralnya Eiger ini bermula dari unggahan@duniadian di Twitter maupun Instagram pada Kamis, 28 Januari 2021. Dian memposting Surat Keberatan yang ia dapat dari Eiger melalui email. Dalam surat itu, Eiger mempermasalahkan video di channel YouTube DuniaDian yang berjudul "REVIEW Kacamata EIGER Kerato Cocok Jadi Kacamata Sepeda". Surat keberatan tersebut ditandatangani Hendra selaku HCGA \& Legal General Manager PT. Eigerindo Multi Produk Industri pada 23 Desember 2020.

PT Eigerindo Multi Produk Industri atau yang dikenal sebagai Eiger merupakan perusahaan manufaktur dan retail peralatan petualangan alam terbuka yang terbesar di Indonesia. Perusahaan ini didirikan pada tahun 1993 oleh Ronny Lukito di Bandung. Nama Eiger, terinspirasi dari gunung Eiger, yakni gunung yang terletak di Bernese Alps, Swiss yang mempunyai ketinggian $3.970 \mathrm{~m}$ di atas permukaan laut.

Berawal dari fasilitas yang sangat terbatas, Eiger meluncurkan produk tas dengan hanya dua mesin jahit. Jalan Cihampelas no. 22 Bandung adalah saksi bisu dirintisnya usaha tersebut, yang kemudian dibuka pula sebuah mini-toko tas di tempat yang sama. Eiger, memproduksi tas dan peralatan petualangan, yang mana terbagi dalam tiga brand utama, yakni Eiger dengan positioning gaya hidup berpetualang (lifestyle adventure), Bodypack dengan positioning e-lifestyle, dan Nordwand dengan positioning kehidupan alam terbuka (outdoor living).

Brand Eiger dikenal luas sebagai brand lokal yang sangat terkemuka di Indonesia. Pada tahun 2009, Eiger terdaftar sebagai Top 250 Indonesia Original Brands dari sebuah majalah bisnis terkenal, Swa Magazines milik Gramedia. Hal tersebut membuktikan kerja keras, tekad kuat, dan komitmen Eiger dari waktu ke waktu dalam rangka meraih kualitas unggul dan nama baik.

Awal mula, Eiger sebagai toko dan produksi kecil dengan hanya dua mesin jahit di jalan Cihampelas 22, enam belas tahun yang lalu kini telah berkembang menjadi market leader dalam bisnis tas dan peralatan petualangan di Indonesia. Sampai saat ini, Eiger telah memiliki 3 Flagship Stores (toko yang menjual produk dengan layanan yang menunjukan value, kehebatan, keahlian dan keunikan), 34 showroom, dan 81 counter tersebar di seluruh wilayah Indonesia.

Informasi yang didapat dari media sosial Twitter Eiger (@eigeradventure), saat ini memiliki 81,8K followers, sedangkan di Instagram Eiger (@eigeradventure) memiliki 2 juta followers. Pada awal tahun 2021, tepatnya 28 Januari 2021 jagad media sosial Indonesia, baik Twitter, Facebook dan Instagram ramai dengan perbincangan soal surat keberatan Eiger terhadap kualitas video yang diunggah Youtubers Dian Widiyanarko. Sontak tagar \#Eiger pun duduk di puncak trending topic di Twitter Indonesia sejak 28 Januari 2021 hingga 29 Januari 2021. 
PT Eigerindo Multi Produk Industri atau yang dikenal sebagai Eiger sempat menjadi trending topic dengan tagar \#Eiger di Twitter setelah mengkritik kualitas video review produk yang dibuat dan diunggah di channel Youtube Duniadian, yang ujungnya adalah blunder Eiger yang menyebabkan terjadinya komunikasi krisis. Berikut data, informasi dan dokumentasi yang kelompok kami dapatkan dari beberapa sumber mengenai kronologis masalah yang terjadi:

1. Bermula dari review produk kacamata yang dibuat dan diunggah di channel Youtube Duniadian. Dian pemilik channel Youtube tersebut awalnya membuat video soal review kacamata EIGER Kerato pada 31 Agustus

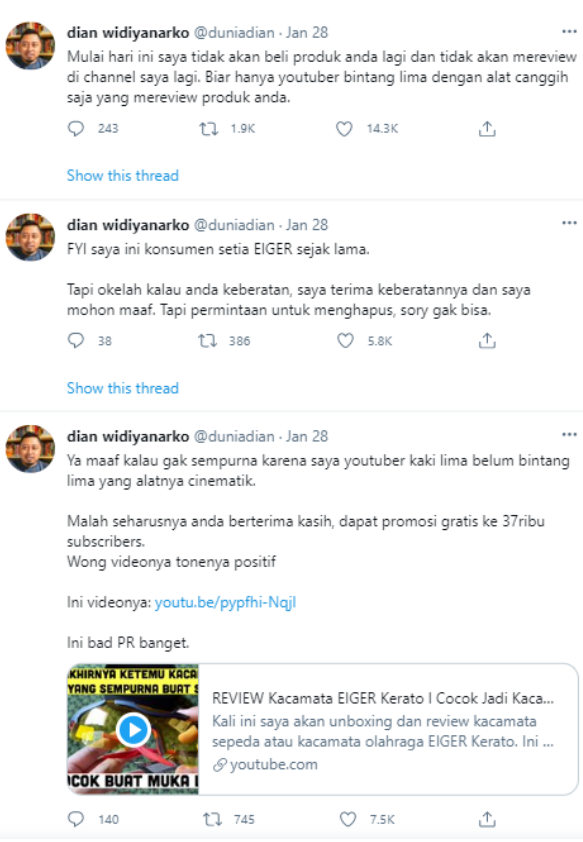
2020. Dalam review tersebut, dia menceritakan bahwa ia membeli kacamata berwarna kuning kemerahan itu karena dirasa cocok dengan bentuk wajahnya. Ia juga menuliskan bahwa fitur wajah tersebut membuatnya sulit mencari kacamata yang sesuai. Dian juga memuji bahwa kacamata sepeda yang dibelinya tergolong pas dari segi harga. Tak cuma itu, Dian juga menyebut produk Eiger memiliki aksesori yang keren pada bagian kaca kuningnya dan kelenturan pada dudukan telinga.

2. Setelah hampir 5 bulan semenjak video review kacamata milik Dian diunggah di YouTube pada Agustus 2020 lalu. Dian justru dihadiahi sepucuk Surat Keberatan oleh Eiger yang dikirimkan via surat elektronik (e-mail). Dalam surat keberatan itu, disebutkan ada tiga poin yang dinilai kurang puas bagi pihak Eigerindo MPI terhadap video "Review kacamata EIGER Kerato" yang dibuat oleh Dian, yaitu:

a. Kualitas video review produk yang kurang bagus dari segi pengambilan video yang dapat menyebabkan produk Eiger terlihat berbeda dari segi warna, bahan, dan detail aksesoris menjadi terlihat kurang jelas.

b. Adanya suara di luar video utama yang dapat mengganggu (noise) sehingga

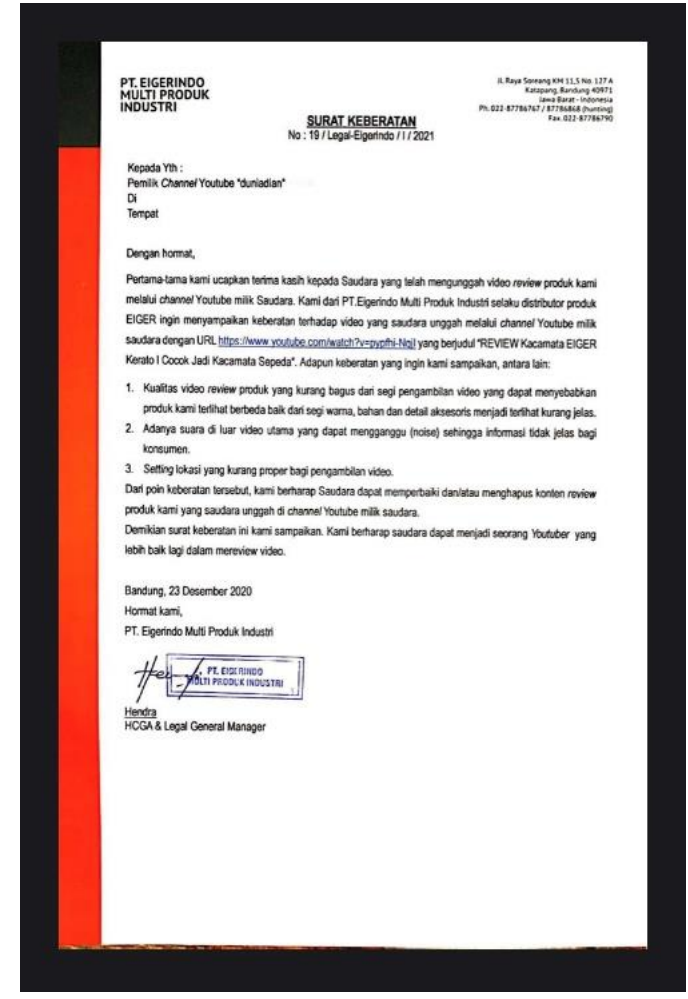
informasi tidak jelas bagi konsumen.

c. Setting lokasi yang kurang propper bagi pengambilan video. 
3. Berkaitan dengan ketiga poin keberatan dimaksud, Eiger pun meminta Dian untuk memperbaiki atau menghapus konten review tersebut. Akan tetapi, Dian menegaskan, ia tak akan menghapus kontennya karena merasa tak ada yang salah dengan apa yang dilakukannya. Lebih lanjut, Dian mengungkapkan bahwa dirinya memutuskan untuk tidak akan membeli produk merek Eiger. Bukannya itu saja, dia sudah terlanjur kecewa dan tidak akan me-review kembali produk-produk Eiger.

4. Selanjutnya, menanggapi unggahan tersebut, warganet sontak ramai berkomentar. Banyak warganet tidak setuju dengan tindakan Eiger yang dianggap kurang tepat. Salah satunya adalah Tirta Mandira Hudhi atau yang dikenal dengan nama dr Tirta. Melalui akun Instagram miliknya, Tirta menuliskan seharusnya merek lokal senang jika ada orang yang mengulas produk mereka secara jujur. Apalagi jika pelanggan yang mengulas juga membeli produknya sendiri. Selain dr Tirta, banyak juga namanama influencer yang ikut meramaikan trendingtopic dengan tagar \#Eiger di Twitter, sebut saja Kaesang Pangarep (@kaesangp), Fiersa Besari (@fiersabesari), Ernest Prakasa (@ernestprakasa), Fajar Nugros (@fajarnugros), hingga Dedy Corbuzier (@corbuzier).

5. Tak lama setelah unggahan itu viral, Eiger mengeluarkan permintaan maaf secara resmi melalui akun Twitter Eiger kepada Dian. Permintaan maaf itu juga diunggah Dian di Instagram. Surat permintaan maaf itu tak hanya ditujukan pada Dian, tetapi juga masyarakat luas. Eiger menyatakan sekaligus mengakui bahwa surat keberatan yang diunggah melalui akun@duniadian benar dikirimkan oleh tim internal Eiger. Permohonan maaf tersebut ditandatangani langsung oleh CEO PT. Eigerindo Multi Produk Industri, Ronny Lukito, dan diunggah di akun resmi Twitter @eigerindo pada Kamis, 28 Januari 2021. Ronny Lukito mengakui, apa yang dilakukan oleh pihaknya tidak tepat dan salah. Tak hanya kepada Dian, Eiger juga membuat "Surat Cinta" yang berisi permintaan maaf yang ditujukan kepada pelanggan setia Eiger atau Eigerian karena telah melakukan kesalahan dan menyampaikan dukungan kebebasan kepada Eigerian maupun para content creator dalam menyampaikan kritik dan saran terhadap produk Eiger. 

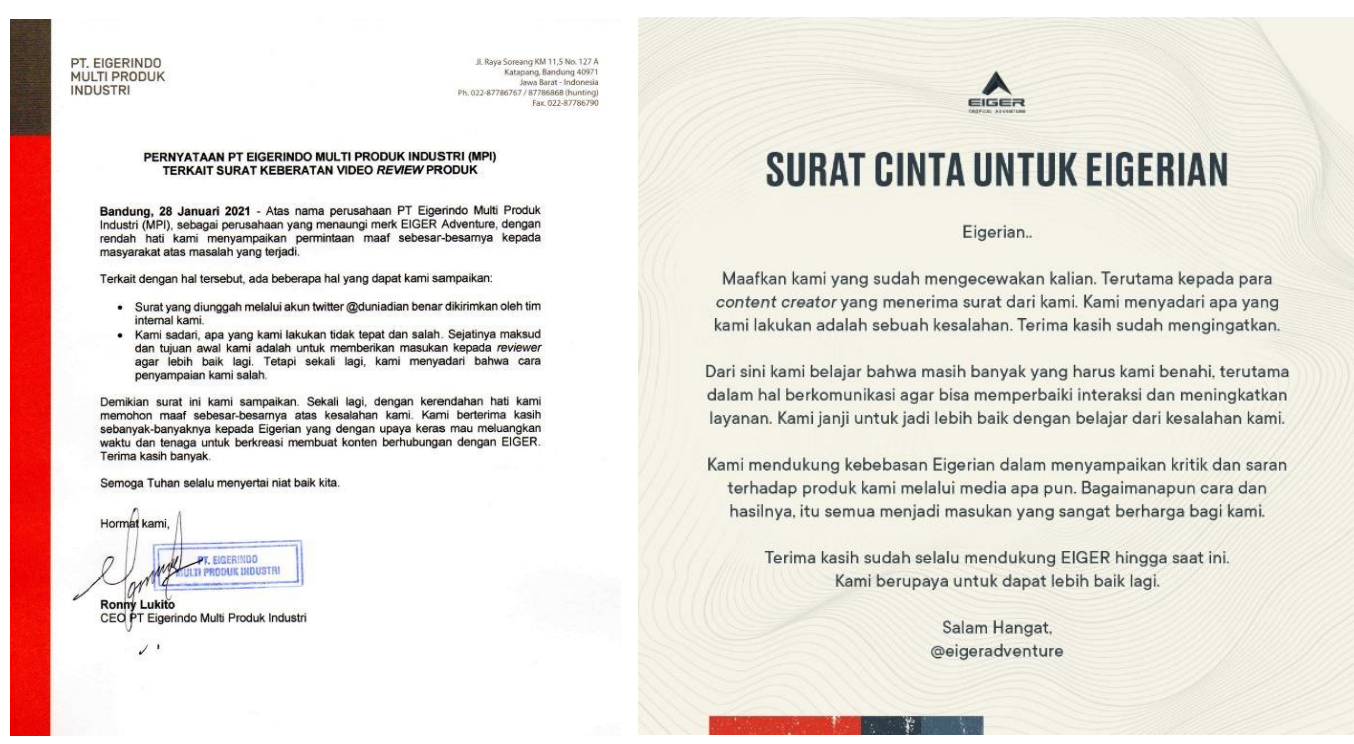

6. Pada 5 Februari 2021, Eiger melalui channel Youtube-nya mengunggah video klarifikasi yang langsung disampaikan oleh Ronny Lukito untuk menjawab pertanyaan dari Eigerian yang bertanya-tanya mengenai kejelasan dari kejadian yang sempat viral terkait Surat Keberatan Eiger di media sosial.

7. Eiger Indonesia menebar diskon untuk semua produknya. Diskon yang ditawarkan mulai dari 20 hingga 50 persen berlaku pada tanggal 12-14 Februari 2021 di Eiger Adventure Store dan Eiger Store di seluruh Indonesia melalui akun media sosial Twitter maupun Instagram @eigeradventure yang dirilis pada Kamis, 11 Februari 2021.

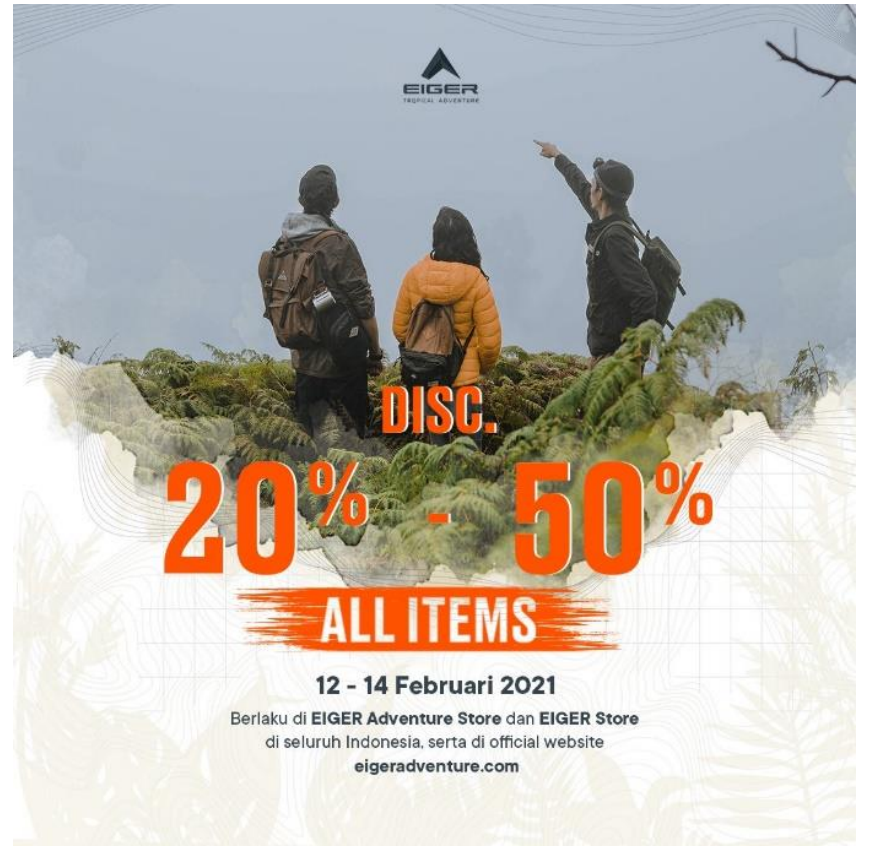


Eiger harus menerima bahwa brand-nya telah mengalami komunikasi krisis dan harus mulai mempersiapkan strategi penyelesaian dalam manajemen krisis. Dari kronologi kasus Eiger yang menimbulkan kontroversial tersebut ternyata tidak hanya berhenti sampai di situ saja. Buntut dari kejadian tersebut ternyata menyisakan beberapa pelajaran dan pengalaman yang berharga baik untuk pihak Eiger sendiri maupun bagi pihak produsen sejenis maupun produsen produk lainnya. Kondisi tersebut menjadi sebuah pengingat bahwa pada era media sosial, berbagai isu bisa dengan cepat menjadi viral dan menarik perhatian.

\section{Metode Penelitian}

Tipe penelitian ini menggunakan pendekatan kualitatif deskriptif dengan metode studi kasus. Penelitian kualitatif dimulai dengan premis dan penggunaan kerangka pemikiran yang akan membentuk atau mempengaruhi studi terkait permasalahan penelitian yang berhubungan dengan makna yang dipakai oleh individu atau kelompok pada suatu permasalahan sosial atau manusia (Cresswell, 2017).

Metode studi kasus digunakan untuk mengumpulkan dan mendeskripsikan fenomena yang ada dengan sedalam-dalamnya melalui pengumpulan data. Seperti yang dikatakan oleh (Mulyana, 2002) bahwa studi kasus merupakan metode penelitian yang sebanyak mungkin memakai berbagai sumber data yang ada sebagai penelitian, kemudian diuraikan dan dijelaskan secara menyeluruh yang berkaitan dengan berbagai aspek dari individu, kelompok atau organisasi, atau suatu program situasi sosial. (Denzin \& Lincoln, 2011) mengatakan jika data untuk studi kasus dapat bersumber dari wawancara, pengamatan, dan atau analisis dokumen. Pada penelitian ini, pengumpulan data yang dilakukan dengan mengacu pada analisis dokumen.

\section{Hasil dan Pembahasan}

Selama perjalanannya, organisasi seringkali menghadapi suatu situasi yang bisa dianggap sebagai krisis. Tidak ada organisasi yang kebal dari krisis dimana pun berada sekalipun organisasi itu waspada dan secara aktif berupaya mencegah krisis. Realitas krisis mengarah pada kebutuhan akan persiapan dan kesiapan untuk merespon, inilah yang disebut dengan manajemen krisis. (Morissan, 2010) mengatakan bahwa manajemen krisis merupakan upaya untuk meminimalisir ketidakpastian dan faktor risiko, sehingga akan lebih mampu menampilkan sebanyak mungkin dari faktor kepastiannya. Komponen penting dalam manajemen krisis adalah komunikasi, dan ketika bidang komunikasi krisis berkembang, penting untuk mengembangkan parameter untuk pertumbuhan itu. (Holtzhausen, D., \& Zerfass, 2014) mengatakan bahwa komunikasi krisis adalah salah satu bentuk komunikasi strategis, dimana komunikasi krisis ini melibatkan penerapan komunikasi strategis untuk membatasi kerugian yang ditimbulkan oleh krisis pada organisasi dan stakeholder.

W. Timothy Coombs mendefinisikan krisis sebagai persepsi peristiwa tak terduga yang mengancam harapan penting pemangku kepentingan dan dapat berdampak serius terhadap kinerja organisasi dan menghasilkan hasil negatif. (W. Timothy \&. 
Sherry J. Holladay Coombs, 2010) menjelaskan proses manajemen krisis dapat diatur secara sederhana dengan model tiga fase, yaitu pra-krisis, krisis, dan pasca krisis. Pada fase pra-krisis, komunikasi krisis berfokus pada penempatan dan pengurangan risiko. Strategi komunikasi krisis pada fase ini diarahkan dengan mengidentifikasi sumbersumber informasi, mengumpulkan informasi, dan menganalisis informasi. Ketiga hal tersebut merupakan aktivitas untuk mengetahui tentang krisis dan menyamakan persepsi di kalangan internal organisasi yang berguna sebagai pembuatan keputusan jika terjadi krisis. Pada fase krisis, model komunikasi yang terjadi adalah dengan mempengaruhi persepsi publik tentang organisasi dan segala upaya organisasi dalam menangani krisis. Sedangkan pada fase pasca-krisis, yang dilakukan organisasi adalah memulihkan reputasi dan mengembalikan reputasi yang sempat hilang akibat krisis.

Terdapat teori yang dapat digunakan untuk memulihkan reputasi dari organisasi, yaitu Image Repair Theory (IRT) yang dikembangkan oleh (Benoit, 1995). IRT dibuat untuk memahami pilihan komunikasi yang tersedia bagi organisasi atau individu yang menghadapi ancaman terhadap reputasi mereka. Meskipun IRT tidak dikembangkan secara khusus untuk komunikasi krisis, tetapi IRT dapat diterapkan karena krisis adalah ancaman reputasi. Berikut strategi tanggap krisis dalam IRT, yaitu:

1. Denial, merupakan strategi dengan melakukan penyangkalan atau dengan mengalihkan kesalahan kepada orang lain.

2. Evasion of Responbility, merupakan strategi dengan melakukan penghindaran tanggungjawab atas pekerjaan atau tindakannya dengan melakukan provocation, defeasibility, atau accident.

3. Reduce of Offensiveness, strategi yang dilakukan dengan mengurangi perasaan negatif dengan cara-cara persuasi kepada public dan menyakinkan public bahwa yang terjadi tidaklah seburuk yang dipersepsikan.

4. Correction Action, strategi yang dilakukan dengan cara mengkoreksi tindakan (kesalahan) yang terjadi dan menginformasikan kembali pernyataan yang benar.

5. Mortification, strategi yang dilakukan dengan mengakui kesalahan dan meminta maaf atas tindakan yang telah dilakukan.

Salah satu teori yang dikembangkan oleh Coombs dan Holladay dalam menangani krisis adalah Situational Crisis Communication Theory (SCCT). Teori ini menerjemahkan Attribution Theory yang dipelopori oleh Bernard Weiner dan Fritz Heider, yang dijadikan dasar teori SCCT dalam komunikasi krisis. Teori Atribusi menjelaskan bahwa manusia cenderung mencari penyebab terjadinya peristiwa atau membuat atribusi, terutama peristiwa yang negatif dan tak terduga (W. Timothy Coombs, 2007). Sedangkan SCCT sendiri berfokus pada bagaimana public relations mencermati situasi krisis untuk menilai tingkat ancaman reputasi organisasi akibat krisis tersebut. Reputasi merupakan konsep penting yang menjadi sorotan SCCT.

Dalam SCCT terdapat dua jenis strategi respon krisis, yaitu strategi respon krisis primer dan strategi respon krisis tambahan. Strategi respon primer terdiri atas tiga kelompok yang didasarkan pada persepsi tentang penerimaan tanggung jawab krisis, 
yaitu (1) menyangkal (denial), (2) mengurangi (diminish), dan (3) membangun kembali (rebuild). Sedangkan strategi tambahannya adalah reinforce (memperkuat) yang merupakan strategi dengan cara mengalihkan fokus dari krisis dengan mengambil tindakan positif dan mengingatkan tentang pekerjaan baik yang telah dilakukan oleh organisasi di masa lalu.

Era digital memiliki banyak implikasi bagi bisnis, termasuk perluasan kekuasaan kepada individu-individu yang sebelumnya terkonsentrasi di tangan media yang terorganisir. Platform komunikasi digital, termasuk blog, jaringan media sosial, dunia virtual, dan wiki, telah memungkinkan konsumen untuk menguasai pesan dan reputasi perusahaan dengan mengikuti jalan pikiran mereka. Media adalah konstituensi dan saluran dimana investor, karyawan, dan pelanggan menerima informasi dan membentuk reputasi perusahaan (Argenti, 2008). Sekarang ini, masyarakat sering kali lebih mempercayai konsumen lain daripada lembaga tradisional, termasuk perusahaan. Salah satunya melalui blog atau channel media sosial yang dimiliki dan dioperasionalkan oleh individu yang disebut dengan blogger ataupun vlogger.

Eiger sebagai salah satu brand dalam bidang produksi peralatan dan perlengkapan kegiatan di alam yang telah menjadi salah satu market leader dalam bidangnya dan telah memiliki loyalitas konsumen jelas tidak berpikir akan berada dalam fase krisis, terutama diantara konsumennya yang loyal. Gagal merangkul internet sebagai alat komunikasi yang aktif dan berpotensi menimbulkan kekerasan memiliki implikasi yang serius. Selain situasi krisis yang dibuat oleh konsumen, perusahaan multinasional besar di seluruh dunia telah dipaksa untuk melawan individu tunggal untuk melindungi merek mereka dan menyebarkan kisah nyata ke media. Inilah yang dialami oleh Eiger di awal tahun 2021 yang sempat viral dan menjadi sebuah situasi krisis di Eiger dan tentunya menggoyahkan reputasi dari brand Eiger yang selama ini dikenal baik.

Brand menurut (Aaker, 1991) adalah nama atau simbol yang menjadi pembeda, seperti logo, trademark, atau desain kemasan yang digunakan untuk mengidentifikasi barang atau jasa dari salah satu penjual atau kelompok tertentu dengan tujuan membedakan barang atau jasa tersebut dari yang dimiliki kompetitornya. Branding menurut (Rampersad, 2008) adalah sebuah proses menciptakan identitas yang dikaitkan dengan persepsi, emosi dan perasaan tertentu terhadap identitas tersebut. Sedangkan menurut (Haroen, 2014) branding adalah aktivitas yang kita lakukan untuk membangun persepsi orang lain terhadap kita mengenai siapa kita. Dari beberapa pengertian tersebut dapat disimpulkan jika branding adalah segala usaha yang dilakukan dalam menciptakan dan membangun sebuah brand.

Seperti yang dikatakan oleh (W. Timothy \&. Sherry J. Holladay Coombs, 2010) bahwa dalam fase krisis, model komunikasi yang terjadi adalah dengan mempengaruhi persepsi publik tentang organisasi dan segala upaya dari organisasi dalam menangani krisis. Pada fase ini, pihak Eiger secara tanggap dan cepat pihak Eiger langsung membuat surat pernyataan yang berisi permintaan maaf secara khusus kepada Dian Widiyanarko selaku pemilik channel Youtube Duniadian, karena pengiriman surat 
keberatan terkait review video produk Eiger yang dikirimkan oleh HCGA \& Legal General Manager Eiger melalui email. Eiger juga membuat "Surat Cinta Untuk Eigerian" yang ditujukan kepada stakeholder untuk meredam kemarahan yang terjadi di berbagai media sosial khususnya di Twitter hingga menjadi trending topic dengan tagar \#Eiger. Yang terakhir adalah video yang diunggah dalam channel Youtube Eiger pada 5 Februari 2021 dengan judul "Klarifikasi CEO Eiger Menjawab", seperti video di bawah ini :

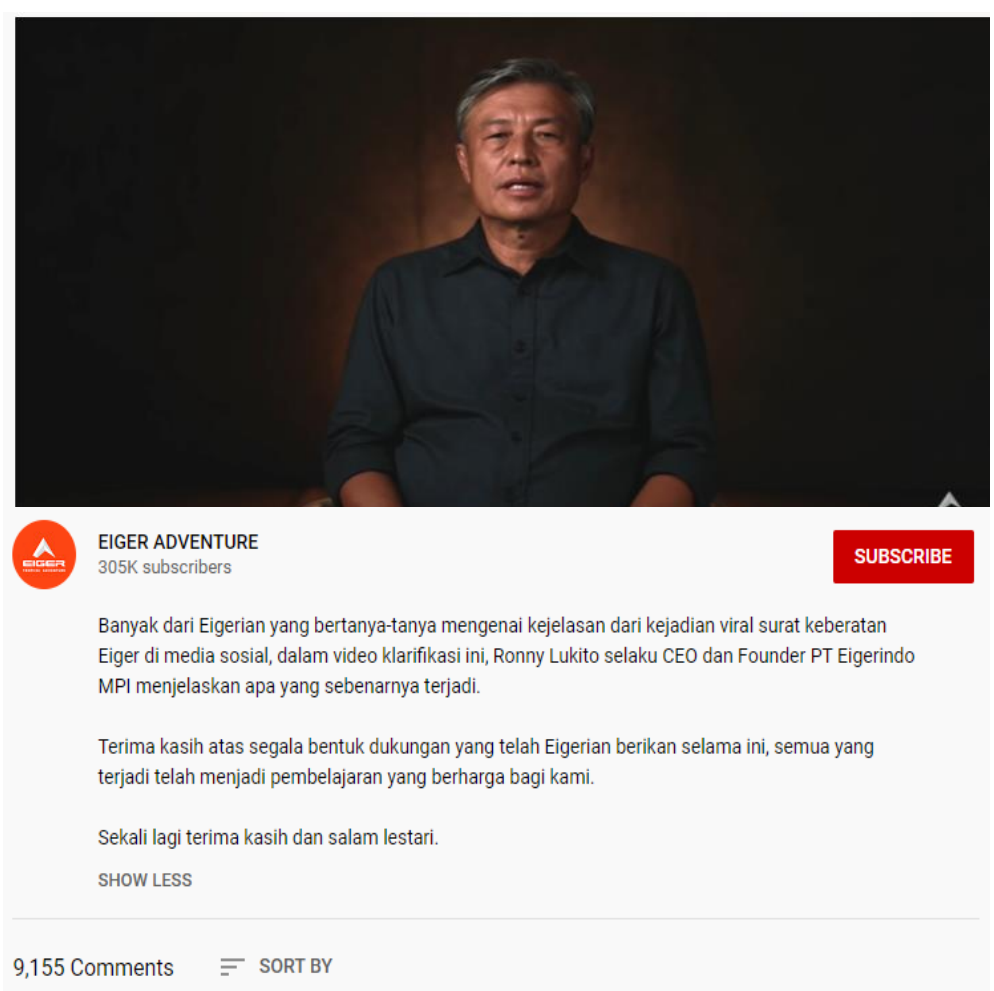

Pada video yang diunggah oleh pihak Eiger tersebut, Ronny Lukito menjadi satu-satunya sosok yang muncul dalam video tersebut. Ronny Lukito menunjukkan dirinya dengan balutan kemeja hitam dan tanpa akseseoris apapun kecuali, sebuah masker putih. Dalam video tersebut Ronny mengawali videonya dengan menyampaikan permintaan maaf atas surat keberatan yang dikirimkan oleh pihak Eiger kepada salah satu konten kreator Youtube, yakni saudara Dian. Ronny juga meminta maaf kepada Eigerian, komunitas, brand ambassador, mitra, para senior advisor, tim manajemen, dan seluruh masyarakat. Selanjutnya, Ronny menjelaskan perihal surat keberatan yang disampaikan kepada Youtuber Dian adalah "murni dari arahan darinya selaku CEO Eiger". Ronny juga menjelaskan bahwa tim internal Eiger telah mengingatkan dan menjelaskan kepadanya bahwa langkah tersebut tidaklah benar dan tepat. Namun, pada saat itu Ronny mengaku tetap bersikeras untuk memberikan surat keberatan tersebut. Ronny juga kembali menekankan bahwa kesalahan sepenuhnya ada pada dirinya selaku CEO Eiger dan tidak ada pihak yang perlu disalahkan. Ronny juga merasa bertanggung 
jawab penuh atas kejadian ini. Ronny juga menyampaikan bahwa pelajaran atas permasalahan tersebut membuat dirinya menyadari untuk menjadi pribadi yang lebih bijak, tidak ego, dan tidak arogan.

Ronny kemudian melanjutkan bahwa ia bersama tim Eiger berkomitmen untuk segera melakukan perbaikan yang menyeluruh atas kebijakan dan peraturan yang tepat, terutama dalam tata cara berkomunikasi dan beradaptasi dengan dunia digital yang berkembang saat ini. Ronny juga mengaku menyadari bahwa ruang digital adalah ruang bebas berekspresi bagi seluruh masyarakat. Ronny juga merasa bersyukur atas pelajaran kali ini yang membuatnya dapat belajar dari yang lebih muda. Ronny mengakhiri video klarifikasinya dengan menyampaikan pesan bahwa "Eiger terbuka bagi teman-teman semua untuk menerima masukan terhadap produk kami melalui media apapun, bagaimanapun caranya dan apapun isinya agar menjadi masukan yang berharga bagi kami”. Ronny kembali berterima kasih kepada seluruh Eigerian dan keluarga besar Eiger yang telah saling mengingatkan dan tumbuh bersama Eiger. Kalimat penutup yang disampaikan Ronny adalah "tanpa teman-teman, tidak ada Eiger hari ini”.

Terakhir, pada fase pasca krisis, yang dilakukan organisasi adalah memulihkan reputasi dan mengembalikan reputasi yang sempat hilang akibat krisis. Berhubungan dengan video di atas sebagai bentuk permintaan maaf sekaligus klarifikasi yang dilakukan langsung oleh CEO Eiger menunjukkan bahwa permasalahan ini sangat penting untuk segera diselesaikan. Eiger juga melakukan upaya perbaikan reputasi dan perbaikan image terhadap brand Eiger dengan memberikan diskon. Eiger Indonesia memberikan diskon untuk semua produknya. Diskon yang ditawarkan mulai dari 20 hingga 50 persen berlaku pada tanggal 12-14 Februari 2021 di Eiger Adventure Store dan Eiger Store di seluruh Indonesia melalui akun media sosial Twitter maupun Instagram @eigeradventure yang dirilis pada Kamis, 11 Februari 2021.

Dengan upaya ini diharapkan para konsumen potensial serta, Eigerian dapat memaafkan dan kembali percaya kepada Eiger dengan komitmen Eiger yang telah disampaikan oleh CEO Eiger Ronny Lukito bahwa Eiger akan melakukan perbaikan menyeluruh untuk kebijakan dan peraturan yang tepat tidak hanya bagi Eiger melainkan juga bagi para stakeholder dari Eiger. Strategi PR yang dilakukan Eiger ini sejalan dengan strategi pemberian kompensasi (compensation) berupa diskon maupun promo dari produk-produk Eiger selama situasi krisis terjadi.

Dari beberapa langkah yang telah dilakukan tersebut, terdapat strategi respon krisis yang digunakan Eiger dalam menghadapi krisis yaitu dengan cara rebuild crisis response strategies yaitu dengan mengakui kesalahan dan meminta maaf atas apa yang telah terjadi (apology). Seperti yang telah dijabarkan pada bagian kronologis serta, analisis pembahasan di atas bahwa setelah menerima keluhan dari yang bersangkutan yang disampaikan melalui media sosial Twitter, Eiger dengan tanggap langsung memberikan pernyataan dini terkait dengan permasalahan yang terjadi serta, langsung meminta maaf kepada yang bersangkutan melalui media sosial. Ini menunjukkan bahwa Eiger dapat merespon dan mencoba menangani komunikasi krisis dengan waktu yang cepat. 
Sedangkan, dalam konsep Image Repair Theory, langkah-langkah yang dilakukan Eiger dalam pemulihan reputasinya menggunakan metode mortification, yaitu dengan mengakui kesalahan dan meminta maaf atas tindakan yang telah dilakukan. Hal ini ditunjukkan melalui pernyataan maaf di media sosial kepada yang bersangkutan, lalu permintaan maaf melalui surat cinta yang ditujukan kepada pelanggan setia Eiger dan Eigerian, dan terakhir melalui video klarifikasi yang diunggah di youtube EIGER yang menyampaikan permintaan maaf dari CEO Eiger secara langsung kepada semua pihak yang terkait dengan Eiger dan merasa kecewa atas permasalahan yang terjadi. Ronny juga memberikan kalimat penutup yang dapat diartikan bahwa ia merasa sangat menyesal atas permasalahan yang terjadi dan mengecewakan banyak pihak. Ronny juga menyampaikan rasa terima kasih atas apresiasi dari semua pihak terhadap Eiger dengan menyampaikan kalimatnya "tanpa teman-teman, tidak ada Eiger hari ini". Kalimat ini dapat diartikan bahwa Ronny merasa sangat berterima kasih kepada semua pihak yang menaruh perhatian atas permasalahan yang terjadi dan sekaligus memohon maaf atas permasalahan tersebut.

Keberhasilan Eiger dalam menghadapi komunikasi krisis yang terjadi bisa terlihat dari strategi tanggap respon dari Eiger yang terbilang cukup cepat, sehingga hanya dalam hitungan jam saja tagar \#Eiger di Twitter langsung menurun dan perlahan hilang dari trending topic. Terbukti dari rencana doxing maupun boikot yang sempat disampaikan oleh warganet pun juga tidak terealisasi. Dan Dian Widiyanarko selaku pemilik channel Youtuber Duniadian pun melalui akun Instagramnya juga telah menerima permintaan maaf dari Eiger.

\section{Kesimpulan}

Di era digital, organisasi harus benar-benar mempersiapkan proses bisnisnya tidak hanya dalam segi pemasaran atau penjualan saja dengan menggunakan teknologi digital, akan tetapi maintenance stakeholder dengan memanfaatkan media sosial secara optimal dan profesional juga diperlukan, dan tentunya dengan cara memperhatikan kode etik yang ada. Adanya kasus komunikasi krisis yang dialami oleh Eiger dapat menjadi pelajaran bagi organisasi atau perusahaan untuk dapat lebih bijak, berhati-hati, dan profesional dalam menyampaikan pesan, berkomunikasi, promosi dengan memperhatikan kemasan dan konten yang diunggah di berbagai platform media sosial yang ada.

Komunikasi krisis merupakan salah satu keadaan yang harus terus dicermati dan diawasi dengan baik untuk mencegah kerugian yang lebih besar. Terutama kerugian atas rusaknya kepercayaan dari pelanggan dan kerusakan reputasi yang dapat mengakibatkan hilangnya pelanggan setia dan konsumen potensial. Hal ini berlaku tidak hanya bagi produsen dalam skala kecil melainkan berlaku untuk semua produsen di segala bidang dan dalam skala global. Khususnya pada saat ini dimana internet mendominasi penyebaran informasi yang tersebar luas dalam jangka waktu yang sangat singkat dimana tidak ada gatekeeper dalam penyaringan informasi yang tersebar. Oleh sebab itu, waspada dan selalu siaga terhadap setiap isu yang berpotensi merugikan ataupun 
melukai brand. Brand juga harus cermat mengenai informasi yang akan disebar karena di internet ada hukum tersirat yakni, "apapun yang telah dipublikasikan tidak dapat ditarik kembali" atau dalam komunikasi dikenal sebagai prinsip irreversible yang berarti komunikasi tersebut tidak dapat dikembalikan.

Komunikasi krisis yang dialami oleh Eiger sebagai brand lokal yang menjadi market leader dalam bidangnya dapat memberikan kita pelajaran bahwasanya reputasi itu merupakan hal yang penting untuk dijaga. Oleh sebab itu, segala upaya yang dilakukan atas nama brand sangat perlu untuk dicermati dengan lebih ketat agar tidak mencederai reputasi dan merugikan brand. Manajemen krisis yang dilakukan oleh Eiger mengindikasikan bahwa Eiger pada saat ini cukup baik dalam mengelola manajemen komunikasi krisis atas brand-nya. Salah satu buktinya adalah dengan keterlibatan CEO Eiger yang langsung meminta maaf dan menunjukkan rasa penyesalan serta, mencoba bertanggung jawab atas permasalahan yang terjadi dengan melakukan klarifikasi.

Dinilai dari beberapa langkah Eiger dalam menghadapi komunikasi krisis yang terjadi di media sosial, Eiger mencoba menyelesaikan permasalahan dengan cara rebuild crisis response strategies yaitu dengan mengakui kesalahan dan meminta maaf atas apa yang telah terjadi (apology). Sedangkan, apabila ditinjau dari teori image Repair Theory (IRT) langkah-langkah yang dilakukan Eiger dalam pemulihan reputasinya menggunakan metode mortification, yaitu dengan mengakui kesalahan dan meminta maaf atas tindakan yang telah dilakukan. Alhasil, Eiger berhasil mengatasi situasi krisis yang sempat terjadi, dan kedepannya menjadi sebuah tugas besar praktisi public relations dari Eiger dalam membangun kembali serta mempertahankan reputasi dari Eiger yang sudah lama dikenal baik oleh masyarakat luas. 


\section{BIBLIOGRAFI}

Aaker, David A. (1991). Managing Brand Equity. New York: Free Press. Google Scholar

Argenti, P. A. (2008). Coorporate Communication ((Fifth Edi). New York: McGrawHill,.

Benoit, William L. (1995). Sears' repair of its auto service image: Image restoration discourse in the corporate sector. Communication Studies, 46(1-2), 89-105. Google Scholar

Coombs, W. Timothy. (2007). Protecting organization reputations during a crisis: The development and application of situational crisis communication theory. Corporate Reputation Review, 10(3), 163-176. Google Scholar

Coombs, W. Timothy \&. Sherry J. Holladay. (2010). The Handbook of Crisis Communication (Handbooks in Communication and Media). United Kingdom: Wiley-Blackwell.

Cresswell, J. W. (2017). Research Design: Pendekatan Kualitatif, Kuantitatif, dan Mixed (Edisi Ketiga). Yogyakarta: Pustaka Belajar. Google Scholar

Denzin, Norman K., \& Lincoln, Yvonna S. (2011). The Sage handbook of qualitative research. sage. Google Scholar

Haroen, Dewi. (2014). Personal branding. Gramedia Pustaka Utama. Google Scholar

Holtzhausen, D., \& Zerfass, A. (2014). The Routledge Handbook of Strategic Communication. New York: Routledge. Google Scholar

Morissan. (2010). Manajemen Public Relations ((Edisi Per). Jakarta: Prenada Media Group.

Mulyana, Deddy. (2002). Metode Penelitian Kualitatif. Bandung: PT. Remaja Rosdakarya.

Rampersad, Hubert K. (2008). Authentic personal branding. Jakarta: PPM Publishing. Google Scholar

\section{Copyright holder:}

Ahmad Faiq Syukron (2021)

First publication right:

Syntax Literate: Jurnal Ilmiah Indonesia

This article is licensed under: 
Komunikasi Krisis Eiger dan Tantangan Perbaikan Reputasi di Era Digital

$$
\text { (c) (i) (?) }
$$

